Comic disjunctions in Goldoni's Il teatro comico

Amalie Vorting Kristensen

Vejle, Denmark

MA Comparative Literature, University of Copenhagen, 2012

A Thesis presented to the Graduate Faculty of the University of Virginia in Candidacy for the Degree of Master of Arts

Department of Spanish, Italian \& Portuguese

University of Virginia

May, 2014 


\section{Comic Disjunctions in Goldoni's Il teatro comico}

\section{Introduction}

This thesis offers a close reading of the comic mechanisms in Il teatro comico (1750) by the eighteen-century Venetian playwright Carlo Emilio Goldoni. Il teatro comico is a play about how to make good comedies, and it is mostly read as a kind of manifesto due to the many rules and regulations it states about playwriting. The approaches advised in the play are part of what critics have called the Goldonian reform of theatre. Goldoni's reformer moved the theater away from the improvised tradition of commedia dell'arte towards the tighter structured and written out plays of la commedia scritta, where the actors memorized specific lines.

In my thesis, I argue that these rules are not just articulated through the meta form of Il teatro comico, where actors play actors who are rehearsing a play, and discuss the proper conventions of playwriting in their dialogs; but that they are also playfully inserted in the wordplays, stylistics and other comic effects of the dialogs. I focus my attention on this additional way these rules and theories are discussed and presented. Through a close reading of different scenes in the play another level of form is revealed. In the rhetorical figures and other comic elements on the level of the text itself Goldoni's ideas about theater reform seem to manifest themselves.

The Italian Goldoni scholar Franco Fido, in his book Nuova guida a Goldoni - Teatro e società nel Settecento from 2000, discusses what he calls "la poetica o programma in azione del Teatro comico" (147). Fido here refers to the meta aspect of Goldoni's comedy about comedies: the actors' playing actors (like themselves) rehearsing a new play (a play within the play) and their dialogs discussing the new conventions of comic theater. Even though Fido recognizes the "telling by showing" approach in the play, or as he calls it, the 
"mettere in azione" of the new style, Fido does not pay attention to yet another, additional way in which these rules are playfully articulated and represented.

Fido states that the reception of Goldoni's comedies has traditionally been ambiguous. Criticism both condemns the lack of poetic value in his plays, and acknowledges their cultural and literary-historical importance. Fido refers here to the great impact that the celebrated Italian critic, Francesco de Sanctis, has had on the reception of Goldoni's plays. Fido writes: "Il giudizio su Goldoni del De Sanctis presentava due facce: la sostenziale negazione di una "poesia" goldoniana da una parte, e il pieno avvertimento, dall'altra, della novità e dell'importanza del Goldoni sul terreno della cultura e della letteratura nazionale" $(5)$.

De Sanctis's reception of Goldoni's work was ambiguous, and at the same time according to Fido, De Sanctis emphasized too heavily the play's lack of a poetic quality. Fido specifies this and additionally noted lacks by other critics, as he writes:

Appunto per ciò dovrò limitarmi a sottolinearne ellitticamente solo alcuni aspetti, scegliendoli di preferenza fra quelli più frequentemente dibattuti in termini negativi dalla vecchia critica positivistica o idealistica: Goldoni nemico o uccisore della Commedia dell'arte; Goldoni cattivo scrittore, Goldoni municipale, superficiale, debole pittore dei sentimenti e delle passioni, e così via. (“Goldoni oggi” 707)

The earlier positivistic and idealistic critics conceived Goldoni as an enemy to the much celebrated and honored oral tradition of the commedia dell'arte, a bad and superficial writer, who did not know how to describe deep emotions and passions. In his introduction to $\mathrm{Il}$ teatro comico Gerolamo Bottoni expresses an ambiguous view implying this kind of critique. As he writes, the play has never been considered one of Goldoni's best, but it has some interesting aspects: 
[Se] la commedia Il teatro comico, che ora figura la prima delle famose sedici, non è certamente la più bella; pure, per aver in essa il Goldoni rappresentati i comici stessi, dei quali seppe cogliere le qualità buone e i difetti; per averli fatti provare una commedia nella commedia, coll'aiuto del suggeritore; per aver saputo far, amabilmente, tollerare il peso della sua teoria teatrale; essa ci viene graditissima, non solo, ma interessante. (Goldoni 6)

Bottoni denies that the play is a literary beauty, but points out other aspects of the play that makes it an interesting case; such as the fact that it is a play about the actors themselves, and that it is multilayered and meta in that sense.

To return to Fido, he wishes to shine a light on the positive part mentioned already by De Sanctis, but not fully examined in Goldoni studies - this part being Goldoni's importance to Italian culture and literary history. Many contemporary scholars have followed this more positive focus advocated by Fido, who writes: "La critica posteriore, e la più recente fino ad oggi, si è esercitata in prevalenza attorno alla revisione di tale giudizio nella sua parte negativa“" (Nuova guida a Goldoni 5). In recent years insightful and informative studies on Goldoni's comedies have been made in the field of gender studies, studies of society and culture in $18^{\text {th }}$ Century Venice, studies of the theatre practices in $18^{\text {th }}$ Century Venice etc. However, instead of avoiding the old discussion about a poetic quality to Goldoni's work this thesis will return to it. Following the contemporary positive outlook advocated by Fido and other contemporary scholars, but engaging in the discussion, instead of avoiding it, this thesis argues that a poetic quality to Goldoni's comedies does exist.

Another important Goldoni scholar Ilaria Crotti in her book Libro, Mondo, Teatro (2000) also describes Il teatro comico as a kind of manifesto that demonstrates while explaining. She writes: "Una pièce programmatica come Teatro comico proietta una luce esemplare sulle scansioni che ricadono nel disegno lettoriale lucidamente trasformato in 
progetto scenico, dove le presunte fatica e noia del leggere verrebbero ricodificate nel piacere della scena" (32). Crotti, in her writings about Il teatro comico, seems to stress a division between a boring and strenuous reading and an entertaining and pleasing stage performance. My analysis serves to show that there is a literary pleasure in the play as text itself. I wish to focus again on the text, and to nuance the statement about Goldoni's lacking poetic qualities. I shall argue that the poetics of Goldoni's reform is put into action on the textual level of the play as well, as a poetica in azione within the wordplays and rhetorical figures of the dialogs.

Consulting the Lacanian inspired Slovenian philosopher Alenka Zupančič and her 2008 book The Odd One In. On Comedy, I examine the comic mechanisms in Goldoni's play using her critical theory about disjunctions and subversive comedy. According to Zupančič in order to be truly comic a comedy must contain elements of disjunctions of meaning and through these a subversion of hegemonic structures occurs. In Il teatro comico Goldoni's wordplays and other comic mechanisms create such disjunctions and thereby also open up to a subversive element on the textual level of the play. This subversive element challenges hegemonic order and meaning, and therefore constitutes a potential critique of social and economic power structures. Understanding Goldoni as subversive goes against customary views of him, and of course there are many differences between an Enlightenment playwright of 18 th Century Venice and a 21 st Century Slovenian psychoanalyst, but both Goldoni and Zupančič try to clarify what effective comedy is. We must therefore keep in mind the difference between the content of Goldoni's instructive bourgeois plots and the play as textual form, separate from its content and historical context. Zupančič is advocating for a radically subversive comedy that challenges us to engage with the fundamentally comic condition of human life, where meaning does not add up. Goldoni wants comedy to be meaningful, useful, instructive and moral. He wishes to educate his audience, and show them the way of rationality, moderation and the golden mean. But there might be something 
subversive in the rhetorical details and other comic elements of his plays. Subversion is a significant element of comedy, as we'll see when analyzing Goldoni's play in the context of Zupančič's comedy theory, and maybe Goldoni was a lot more subversive in his comic form than he is often understood to be. Theory and terminology will be introduced and explained throughout the paper.

\section{Behind the curtains of the mysterious comedy}

There is a certain kind of mystery to the topic of comedy. Goldoni in Il teatro comico points to the speculations and misunderstandings as a consequence of the missing portion of Aristotle's Poetics which concerned comedy and laughter. Goldoni remarks on this in the mouthpiece of one of his characters. "ORAZIO. Vi spiegerò io cosa dice Aristotile. Questo buon filosofo intorno alla commedia ha principiato a scrivere, ma non ha terminato, e non abbiamo di lui, sopra tal materia, che poche imperfette pagine" $(2,3)$. These few un-finished pages are also mentioned by Zupančič, who draws our attention to the "comic" fact that Aristotle's book on comedy is missing: "Philosophy's relationship to comedy is not exactly a simple story, although it contains [in] itself some elements of comedy, starting with the disappearance of the book that might have inaugurated philosophy's more canonical interest in comedy" (3).

This mysterious book on comedy by Aristotle has in fact in recent Italian literary history played an important role, as it is the key to the world renowned novel Il nome della rosa by Umberto Eco. In Eco's novel a fanatic monk, Jorge, guards the one surviving copy of Aristotle's book with his life, hiding it in the labyrinthine library of a medieval monastery. Jorge is convinced that laughter is Satan's work, and that if the content of Aristotle's book on comedy were to become generally known, it would threaten the very foundations of the Christian church. Zupančič also mentions Eco's novel and although she hurries to say that the 
dichotomy that the novel puts forth between a rigid fanaticism of ideology and a liberating playful irony is much too simplistic, nonetheless Il nome della rosa thematizes the overall idea of a disturbing and mysterious aspect of comedy that is perfectly in line with Zupančič's comedy theory and Goldoni's Il teatro comico.

The very first scene of Goldoni's play supports a sense of mystery as viewers (or readers) are allowed a peek behind the curtains on a stage where a theater group is about to rehearse the third act of a play called Il padre rivale al figlio. The opening of Il teatro comico is a discussion between the manager of the theater group, Orazio, and one of the actors, Eugenio, about whether to raise or lower the curtain before they start rehearsing the new play. ORAZIO. (verso la scena) Fermatevi, fermatevi, non alzate la tenda, fermatevi. EUGENIO. Perché, signor Orazio, non volete che si alza la tenda?

ORAZIO. Per provare un terzo atto di commedia non ci è bisogno di alzare la tenda.

EUGENIO. E non ci è ragione di tenerla calata.

ORAZIO. Signor sì, che ci è ragione di tenerla calata, signor sì. Voi altri signori non pensate a quello che penso io. (verso la scena) Calate giù quella tenda. EUGENIO. (verso la scena) Fermatevi. Se si cala la tenda, non ci si vede più, onde, per provare le nostre scene, signor capo di compagnia, vi converrà far accender de' lumi.

ORAZIO. Quand'è così, sarà meglio alzar la tenda. (verso la scena) Tiratela sù, che non voglio spendere in lumi.

EUGENIO. Bravo, viva l'economia!<smiles>C1[AlH]C[AlH]1</smiles>

EUGENIO. Vorrei sapere per qual causa non volevate alzare la tenda?

ORAZIO. Acciocché non si vedesse da nessuno a provare le nostre scene. 
EUGENIO. A mezza mattina, chi ha da venire al teatro?

ORAZIO. Oh, vi sono dei curiosi, che si leverebbero avanti giorno. $(2,1)$

This meta-opening of the play suggests that the actual audience has special access to the back stage to see what happens behind the curtains when a play is rehearsed. At first glance the essence of the scene might appear to lie solely in the lazzo of pulling the curtain up and down. (On the command of Orazio and Eugenio the theatre workers pull the curtain up and down, up and down). There is more at work, however, than the classical lazzo. The argument about whether to keep the curtains up, points to letting the audience in on the secrets of how to make comedy. Orazio does not want anyone to see the rehearsal of the new play. He does not want the public to know what the play is about (new plot) nor how it's done (new witty lines and other comic effects). The actual audience becomes these "curiosi" that Orazio talks about, who have gotten up early to go to the theatre. The opening of the play points our attention to the fact that Il teatro comico is a meta play about playwriting and acting, and it arouses our curiosity, as we are let behind the curtain to see the workings of comedy. In order to examine and unfold Goldoni's comic workings, I shall look closer at Zupančič's theory on comedy and her idea of the comic disjunction.

\section{Zupančič's theory}

Alenka Zupančič is a Slovenian philosopher with a Lacanian background. She is part of The Slovenian School, which, led by her countryman, Slavoj Žižek, in recent years has written books and essays in the field of psychoanalysis and critical theory.

In her book The Odd One In - On Comedy (2008) Zupančič embarks on an ambitious task to define true comedy and reveal its subversive quality. This subversive quality is a disturbing and critical potential that Zupančič identifies as essential to true comedy. She wishes to give comedy back its cutting edge in a contemporary climate that demands that we 
be happy and enjoy; an ideological climate where an immediate and causative link is established between our feelings of happiness and enjoyment and our worth as human beings. This connection between enjoyment and human worth follows the logic that if we are happy and enjoying, we are good people. In Zupančič's view, this kind of entertainment, based in a "positive thinking" ideology, functions to create harmony, reconciliation and self-acceptance, and thereby blocks the disturbing and critical side of comedy. For Zupančič the disturbance and critique inherent in comedy is necessary for it to function at all. It is a good thing and hence should not be blocked. As she writes in her introduction:

It is as if the imperative of entertainment, "positive thinking," and immediacy were blocking the very heart of comedy, its sparkle, and had blunted the edge on which both comedy and our sensibility to it live and thrive. It is the (im)modest ambition of this book to conceptually revive this edge. (9) Zupančič wishes to reveal the disturbing aspect of comedy and allow its critical sparkle to be seen. She challenges the ideological imperative of entertainment and harmony. In order to better understand her critique of the imperative of entertainment and immediacy, I shall briefly look at some of her underlying Lacanian ideas.

Jacques Lacan is a post-war French philosopher combining Freud's psychoanalysis with structural linguistics. He is inspired by the French linguist Ferdinand de Saussure's notion of language being arbitrary, which means that it does not have an immanent meaning in itself but instead constructs meanings in the semiotic relations of its signs (signifiers). Lacan in his introduction to Écrits I writes that "il n'y a de maître que le significant" (the only master is the signifier) (7). "Master" should be understood as the dominant idea, or that which determines meaning in a given ideological system of signs.

Keith Reader explains Lacan's point about the Master-signifier and states that we are not as in control as we might think we are, of language, our own expressions, and meaning. 
Lacan points out that signifiers enter into play with themselves and create systems of meaning not entirely originated and orchestrated by us. Reader, in his gloss on Lacanian theory, calls these systems of meaning "the law of language" and interprets Lacan as saying that: "human subjects are, precisely, subject to the laws of language, and that it is in and through those laws that our identities are articulated" (214).

Thus we are never the only generators and manipulators of meaning, and there is not an immediate relationship between our meaning and us, because language comes in between. We are dependent on language and other signifiers to understand and express ourselves, and at the same time, we are not fully in control of these signifiers, since they keep entering in semiotic play with other signifiers, and sometimes the connection of signifiers is broken, and meaning collapses. As Reader states: "any notion of a self always and fully present to itself is always and everywhere illusory" (214). Our innermost feelings, our unconscious and desires are not immediate and do not belong to us, since they are dependent on signifiers.

Returning to Zupančič's critique of the entertainment imperative wherein modern entertainment and comedy are based on a "positive thinking" ideology, comedy is a "lesson meant to show us our mere humanity - to teach us that we are not perfect, that after all we are only human, that we should simply accept our weaknesses, limitations and imperfections" (Kottman 4). Zupančič faults "positive thinking" and its enjoyment imperative for its attempt to close and bring under control the gaps and contradictions in the subject's self-constitution (our innermost feelings are not immediate and natural, but dependent on uncontrollable signifiers) instead of engaging with the instructive meanings produced by those very gaps and contradictions.

For Zupančič comedy owes its very existence to these gaps and contradictions; comedy lives in the instances when the meaning equation doesn't easily add up, when meaning doesn't neatly and tightly fit its container. This idea about something not fitting and 
leaving a surplus, something extra that cannot be expressed, represented or understood stems again from Lacan, and precisely his idea of the "Real." The Real is what is outside of the imaginary order of the self and outside the symbolic order of language, it is what cannot be imagined or signified.

Lacanian thought goes on to specify that this surplus of the Real doesn't exist as such, because we cannot describe or imagine it, since it's outside the "field" of signifiers. It can be understood only as a lack, a gap (rupture, disjuncture), a disconnection or incongruence. It is what comes forth when meanings do not add up, and mismatches result. Zupančič uses many different synonyms to describe these valuable mismatches. In the citation below she uses the terms "short circuit" and "cut", but I will tend to use "disjunction" to describe these mismatches producing a surplus that at the same time is a lack in meaning:

...comedy thrives on all kinds of short circuits that establish an immediate connection between heterogeneous orders. [...] the immediacy that comedy [...] puts forward is not that of a smooth, imperceptible passing from one into another, but that of a material cut between them. If we think of the simplest examples of this procedure (like the one frequent in the Marx brothers' comedies when say, A says, "Give me a break!" and B pulls a brake out of his pocket), [comedy's] fundamental lesson is always this: the only genuine link between these two things is the very cut [disjunction] between them. (8)

Comedy, in Zupančič's understanding of it, happens when we become aware of the gaps and contradictions of the human condition and life. She writes: "If humans were 'only human(s)' (and life 'only life'), if the human equation indeed added up so neatly and with no remainder, there would be no comedy" (49).

Paradoxically then, the connection made by comedy is at the same time a disconnection or rupture. It is not a continuous flow of shifting meanings in the free play of 
signifiers (that keeps being affected by different semiotic contexts). The comic connection is rather a rupture, disjunction or disconnection in such a flow among signifiers and meanings, and shows the missing links between heterogeneous orders. In the example above the (dis)junction is that of an idiomatic expression (give me a break) and a material thing (a brake).

Comedy furthermore thrives on sequences of events that all involve the mechanism of disjunction. It runs on relationships and back-and-forth between terms. In order for this comic (dis)junction to produce a longer comic sequence, it must enter in a process that includes a dynamic and involves movement. Furthermore the "terms" between or among which the disjunctions emerge are infinite, and therefore the movement of comedy can apply to many different situations. It can be two characters fighting over the same identity, it can be a character fighting him- or herself, and thereby showing a disjunction in the personality which is normally conceived as a unity. In the second part of her book, Zupančič shows though numerous and diverse examples taken from jokes, theater and pop culture how the comic mechanism of cut or disconnection always involves movement.

As we shall see in the following analysis, a comic sequence of disjunctions can also be understood as comic movements of words. My analysis of the following scene from $\mathrm{Il}$ teatro comico will show this mechanism of disjunction and the comic movement. I will argue that via this comic movement Goldoni's play has a playfulness, which adds a poetic quality that earlier critics said was missing; and that this playfulness is subversive in its form and makes Il teatro comico truly comic in Zupančič's understanding of the term. 


\section{Lelio's dialog}

As mentioned in the beginning of this thesis Il teatro comico gets its manifesto nature because it is a play about how to write good plays. In the first scene we're invited to take a peek behind the curtains, as a group of actors and their manager, Orazio, rehearse the last act of a new play. We will not get to see the rehearsal, though, until the end of Il teatro comico, because the actors are late (especially the women), other artists unexpectedly come for auditions, and lively discussions about gender roles, good customs, and most importantly rules about playwriting and actors' performances keep postponing the rehearsal.

The scene I'm focusing on is a scene where the starving poet Lelio, a poet of the old school, fighting for his livelihood, has come to the theatre to sell a play to the actors of Goldoni's new school. They are all gathered and Lelio tries to impress them by reciting a scene from his play, a highly eloquent dialog between two lovers.

LELIO. Sentite almeno questo dialogo.

ORAZIO. Sentiamo il dialogo.

LELIO. Dialogo primo, Uomo prega, Donna scaccia. Uomo. Tu sorda più del vento, non odi il mio lamento! Donna. Olà, vammi lontano, insolente qual mosca, o qual tafano. Uomo. Idolo mio diletto....

ORAZIO. Non posso più.

LELIO. Abbiate compassione....

ORAZIO. Andategli a cantar sul colascione. (parte)

LELIO. Donna. Quanto più voi mi amate, Tanto più mi seccate. Uomo. Barbaro cuore ingrato.

EUGENIO. Anch'io, signor poeta, sono seccato. (parte)

LELIO. Donna. Va' pure. Amante insano, Già tu mi preghi invano. Uomo. Sentimi, o Donna, o Dea 
PETRONIO. Oh, mi ha fatta venire la diarrea!

(parte)

LELIO. Donna. Fuggi, vola, sparisci. Uomo. Férmati, o cruda Arpia!

BEATRICE. Vado via, vado via.

(parte)

LELIO. Non far di me strapazzo

PLACIDA. Signor poeta mio, voi siete pazzo.

(parte)

LELIO. Donna. Non sperar da me pietà, Che pietà di te non ho. Uomo. Se pietà da te non ho, Disperato mirirò. Come! Tutti son partiti? $(1,11)$

This sequence from the play shows Goldoni's witty critique of the improvised tradition of commedia dell'arte. In the commedia dell'arte tradition highly skilled and well-read actors improvised scenes drawing on pre-determined topics and only following an outline (canovaccio) of the theme they should perform. We encounter one of these traditional topics as Lelio presents his dialog: Dialogo primo, Uomo prega, Donna scaccia. The scene is that of a desperate male lover and a dismissive woman. The scene is outlined, and the actors fill in with improvised but highly elaborated and stylistic dialogs and speeches. As we can tell by the citation from Il teatro comico, the actors of the new school are not impressed nor pleased with Lelio's old style dialog.

In Goldoni's new style the dialogs were written out and memorized by the actors. Goldoni's criticized the commedia dell'arte because in his opinion it had become boring and old. Audiences who had seen these themed scenes before only with minor variation already knew them. Also, according to Goldoni, the scenes were excessive and vulgar in their attempt to entertain. Orazio, the manager of the theater group and the voice of reason in Il teatro comico, gives voice to this disapproval of the cattivo gusto inherent in the vulgar language and beatings $(1,11)$. Already in the very first scene he laments old-school habits, such as long speeches, as he discusses how best to use actors with another member of the theater group Eugenio: 
ORAZIO. Quando si vuol mettere in grazia un personaggio, conviene farlo un poco desiderare, e per farlo comparire, bisogna dargli poca parte, ma buona. EUGENIO. Eppur vi sono di quelli che pregano i poeti, acchiocché facciano due terzi di commedia sopra loro.

ORAZIO. Male. Malissimo. Se sono buoni, annoiano; se sono cattivi, fanno venir la rabbia. $(1,1)$

According to Orazio, if actors are given too much time, making long improvised and ornamented speeches at best are boring, because the audience knows the speeches already. If they are badly done, they are just insufferable. That the old style is insufferable to the actors of the new school is expressed very directly in their comments, for example when Orazio says: "Non posso più," or Eugenio’s reply “Anch'io, signor poeta, sono seccato.” Petrino gets physically ill by listening to Lelio’s dialog: "Oh, mi ha fatta venire la diarrea!”

If we look a little closer at Lelio's dialog uomo prega, donna sciaccia we can detect some of the stylistics and rhetorical figures that Goldoni uses to playfully denounce the old style, since these figures were endemic to that style. One example is the repetition of words that all mean almost the same: Fuggi, vola, sparisci. Another example is the traslati, or metaphors for the woman in o Donna, o Dea [...] o cruda Arpia. The monotone stylistic rhythm of syntax and rhymes in the list of antitheses: cuore ingrato, amante insano, preghi invano and the chiasmus at the end: Non sperar da me pietà, Che pietà di te non ho are other examples. Lelio provides concrete examples of the old style, and shortly after the scene, Goldoni seems to comment directly on the stylistics in this exchange where the actress Placida rejects the old-style techniques Lelio tries to sell her.

LELIO. [...] vi darò io delle commedie scritte con uno stile sì dolce, che nell'impararle v'incanteranno.

PLACIDA. Basta che non sia stile antico, pieno di'antitesi e di traslati. 
LELIO. L'antitesi, forse, non fa bell'udire? Il contrapposto delle parole non suona bene all'orecchio?

PLACIDA. Fin che l'antitesi è figura va bene, ma quando diventa vizio è insoffribile.

LELIO. Gli uomini della mia sorta sanno da i vizi trar le figure, e mi dà l'animo di rendere una graziosa figura di ripetizione la più ordinaria cacofonia. $(2,2)$ In this humoristic and feisty discussion between Lelio and Placida very specific rhetorical figures such as antithesis, metaphor and repetition are mentioned, and these are exactly the same figures found in Lelio's dialog between the begging man and the rejecting woman.

If we next look closer at the interferences and responses that the actors make within Lelio's speech, we see Goldoni's "telling by showing" in the rhetorical details of the text. This is also where the sequence becomes comic in Zupančič's understanding of the term. Goldoni's mocking of the old style through Lelio's exaggerated performance is funny in itself, but when the actors start to join the dialog the real comedy happens.

First one notes the analogy between the characters of the dialog Uomo prega, donna scaccia and the roles of Lelio and his audience. Lelio is not a desperate male lover, but a desperate male poet, and his reluctant audience, who does not want to hear his speech, mirrors the role of the rejecting woman. Already at this level (of the content of the dialog) we find a comic junction that also constitutes a cut or disjunction in Lelio's speech, since the interventions of the actors create a surplus of meaning that does not add up. Two different conversations are happening at the same time, and they are only connected through an interruption or disjunction of Lelio's speech. A (dis)junction occurs between the two heterogeneous orders, one being the presented dialog uomo prega, donna scaccia and the other Lelio and his own situation at the theatre. 
We see how Goldoni's droll critique is played out on different levels: First, as a critique of the commedia dell'arte and the oral improvised tradition, through a mocking of the rhetorical figures and ornamental style of the old school, and second, through the analogy between the dialog uomo prega, donna scaccia and Lelio's own situation as a begging poet in front of a rejecting audience. If we look even closer at this scene, we can see how the comic mechanisms function on yet another level.

The reactions from Orazio and the rest of the company repeat and rhyme with the words from Lelio's dialog, but in their connection, they also make a disjunction of meaning. Repeating words such as "seccate/seccato", "strapazzo/pazzo" and rhyming "compassione" and "colascione", "Dea" and "diarrea", "Arpìa" and "via" connects the two different orders, but this connection also generates a disruption. The meaning of the first line of Lelio's dialog between the two lovers "Tu sorda più del vento, non odi il mio lamento! and "Abbiate compassione" changes when Orazio rhymes "compassione" with "colascione," because Lelio's lament about someone not willing to listen, seems retrospectively to be addressed to Orazio, as Orazio replies: “Andategli a cantar sul colascione.” In the same way, when Petrino exits, the meaning of Lelio's next line "Fuggi, vola, sparisci” suddenly changes too, and seems to comment on Petrino's leaving. The actors' reactionary comments and actions retrospectively change the meaning of what has been said before, "showing how one of two series has already-always been inscribed in the other" (Zupančič 141-142). Zupančič explains a comic sequence as follows:

In comedy, there is first an unexpected sparkle (a kind of inaugural joke), and the unexpected surplus it produces is not conclusive, but functions as the motor of the subsequent comic sequence. One could also say the inaugural surplus introduces a fundamental discrepancy that drives comedy further and further, 
and it is this surplus/discrepancy itself that serves as the "glue" of the comic events. (139-140)

This crossing of two heterogeneous orders is at the same time a junction and a disjunction, and such a (dis)junction creates a surplus of meaning. But the (dis)junctions don't stop here, since the surplus produces yet other mismatches of meaning, generating a subsequent movement of disjunctions. Lelio's dialog clearly exemplifies this process. Starting out as a dialog between two lovers, it becomes a dialog between Lelio and his listeners. The listeners' engagement with and responses to the dialog cited by Lelio cause the two orders (Lelio's dialog and the actors' responses) to swing meaning back and forth in a sequence of mismatches where the meaning continues to change retrospectively.

Goldoni's (play)writing becomes a "telling by showing" as he both ridicules old-style dialogs and shows how the new style's thoughtful and scripted wordplay and interactions between the actors can produce great comedy. On the level of the play as text the comic disjunctions create a comic sequence and show a potentially radical and subversive aspect inherent in Goldoni's comedy.

\section{The comic character}

Another way in which comic disjunctions and movements function in Goldoni's play through the character of Lelio is in his role as a comic character par excellence, who constitutes a walking, talking, comic (dis)junction. Goldoni states in Il teatro comico that his plays are character plays. After Lelio has recited his dialog, and the whole company of actors has left him, he is desperate and asks Anselmo for advice. Anselmo tells him that these kind of pre-structured dialogs, lazzi and metaphors are not used anymore. Instead, Anselmo informs Lelio that his theater group does character plays:

$$
\text { LELIO. Signor Anselmo, son disperato [...] }
$$


ANSELMO. Ma no sala che dialoghi, uscite, soliloqui, rimproveri, concetti, disperazione, tirade, le son cosse che no se usan più.

LELIO. Ma presentemente che cosa si usa?

ANSELMO. Commedie di carattere.

LELIO. Oh delle commedie di carattere, ne ho quante ne voglio.

ANSELMO. Perché, donca, no ghe n'ala proposto qualcheduna al nostro capo?

LELIO. Perché non credeva che gl'Italiani avessero il gusto delle commedie di carattere.

ANSELMO. Anzi l'Italia adesso corre drio unicamente a sta sorte de commedie [...] Adesso, che se torna a pescar le commedie nel Mare Magnum della natura, i òmeni se sente a bisegar in tel cor, e investindose della passion, o del carattere, che se rappresenta, i sa discerner se la passion sia ben sostenuda, se el carattere sia ben condotto e osservà. $(2,1)$

As Anselmo explains, the new Italian theatre wants character plays. Character plays are dominated by strong conventional characters (originally masks), who represent certain personalities or traces of a personality. Goldoni finds inspiration for these characters in the surrounding eighteen-century Venetian society, and his actors imitate passions and people from real life situations. The audience is supposed to learn from the bad habits, misfortunes, passions and virtues of others.

At the end of their talk, Anselmo promises to talk to Orazio, and to try to persuade him to listen to Lelio's plays one more time. But before he leaves the stage to go do that, we hear him say: "Vado da sior Orazio, e spero che el vegnirà a sentir subito cossa che la gh'à circa ai caratteri. (da sé) (Ma credo, che el più bel carattere de commedia sia el suo, cioè el poeta affamado)" $(2,1)$. According to Anselmo, the greatest comic character is Lelio himself, and the title of his play should be The Famished Poet. Anselmo doesn't specify why Lelio is 
a great comic character, but clearly he is more amusing than sad. What is it that makes Lelio's character so comic?

We might get a better idea about what makes Lelio amusing by examining what makes a character comic. Zupančič defines a comic character as the perfect extension of a comic disjunction. A character, Zupančič states in her psychoanalytical terminology, shows the (missing) link or the disjunction between the Ego and the Id. A comic character shows this (dis)junction between two parts of the same personality (Ego and Id). The Ego and the Id appear on stage simultaneously as two entities separated but still somehow connected, and we see a material manifestation of the disjunction, an impossible coexistence of two nonrelatable realities. As Zupančič writes “...we are dealing not so much with the protagonist's "inner struggle" as with the fact that the Id - incarnated in an external object or ritual literally swings the character around, as if they were tied together by an invisible elastic band" (67). This (dis)junction between the Id and the Ego can be exemplified by the old psychoanalytical joke, where one person greets another: "How is it going?" The answer to the greeting is: 'It (Id) is going very well. But me - well, that's another matter. I'm tired, I'm depressed, my back aches." The joke shows a split between the Ego and the Id, two entities normally conceived as one and the same (Zupančič 63). Zupančič uses this discrepancy to define a comic character. She uses terminology taken from German psychoanalysis.

A well-known comic device to ensure an extended short circuit $[\ldots]$ is the invention of the Character. "Character," as invented, is something other than a "strong personality," a hero o a heroine. [...] Characters (or character comedies) are indeed the prominent form taken by the figure of comedy that I have defined as that of the Ego and the It [Id] - [because] its singular, exclusive, and appropriately overemphasized relation to the It [Id] [...] makes an Ego a Character. [...] Characters are defined by the fact that they are driven utterly 
and exclusively by some kind of passion or passionate attachment, this passion being incarnated in an external object or ritual, which sort of drags these characters along, implicating them in all sorts of possible and impossible situations. (66-67)

According to Zupančič a character is defined by a (dis)junction in his personality that shows the split between its Ego and Id. The character's Id might be enjoying itself pursuing some kind of passion incarnated in an object or ritual, while the Ego is dragged around the stage ending up in all sorts of possible and impossible situations trying to fulfill the Id's needs.

Lelio is such a comic character. His Id is hungry, and he is basically searching for a job so he can be offered a meal or pay for one. The Id will do anything to get accepted by the theater group, and he always says he has what they ask for. The Id becomes external and material through Lelio's unrelenting passionate attachment to finding a job/food. The Ego is dragged around and made to do whatever the Id commands: if the audience (and the Id who wants to please them) wants a nice dialog, the Ego is made to do it. If they want character comedies he must do it; he must sing, dance and even act to try to please the Id. In this way Lelio manifests and materializes the (dis)junction between his Id and his Ego.

In the dialog that I have analyzed above, the Id is so caught up in trying to impress his audience that he doesn't even notice that they have all left: "LELIO. Donna. Non sperar da me pietà, Che pietà di te non ho. Uomo. Se pietà da te non ho, Disperato mirirò. Come! Tutti son partiti? Me hanno piantato? Così scherniscono un uomo della mia sorte? Giuro al cielo che mi vendicherò" $(1,11)$. We already know that Lelio's Id will do anything to get a job, so when he talks about being betrayed and getting revenge, it seems like it's his Ego that talks, and not his hungry Id that got him in the embarrassing situation in the first place. A little later, when Orazio comes back to give him one last chance to prove himself, Lelio has just been eloquently insulted by Placida, and he again seems to be struggling between his Id and 
his Ego: "LELIO. Queste principesse di teatro pretendono aver troppa sovranitá su i poeti, e se non fossimo noi, non riscuoterebbero dall'udienza gli applausi. Ma ecco il signor capo; conviene contenersi con esso con umilità. Oh fame, fame, sei pur dolorosa!" $(2,3)$. Lelio is torn between his pride - his idea of himself as a respectable poet - (the Ego) and his desperate need for food (the Id). The need of food in itself does not so much constitute his Id, since the object of his desire could just as well be any other. But that which causes the problem is his unyielding desire and need to get this object, in spite of any obstacle, insult or dishonor it might cause for his Ego.

This analysis of Lelio's comic character shows a disjunction between his Ego and his Id. Goldoni, through Eugenio's aside, calls Lelio the best comic character, and indeed, Lelio seems to be the protagonist of the Il teatro comico exactly because of his strong comic character. This argument is supported by the fact that the play Padre rivale del figlio - the play rehearsed in Il teatro comico - takes up a much smaller part of Il teatro comico compared to all the discussions leading up to it. When the rehearsal finally starts, Lelio keeps interrupting to make comments.

\section{Pantalone and the banana peel}

Lelio with his strong comic character is a walking, talking (dis)junction and seems to be the protagonist of Il teatro comico. In the following, I shall examine the comic disjunction that is at play in the case of Pantalone, who respectively seems to be the protagonist of the play within the play, Padre rivale del figlio.

The play inside the play presents a range of the commedia dell'arte's comic masks, among which we find the famous characters of Pantalone and Il dottore, the young lovers, Brighella, Arlecchino and Colombina. The main character, at least in act III of Padre rivale del figlio where the actors start rehearsing the play, is Pantalone. He is the one causing all the 
trouble because he is in love with Il Dottore's daughter, Rosaura, who is meant to marry his son, Florindo.

The comic mechanism at work in the case of Pantalone can be described by a classic example of comedy where a toffee-nosed baron slips on a banana peel. One way to understand this comic sequence is in the relieving effect it has on the audience. When the baron slips, the tense self-importance with which he carries his status is revealed. In his slip the baron is reduced to a common bodily human being, who is subject to the laws of gravity like everybody else.

Kottman explains, however, that this is a conservative and "wrong" way of understanding the comedy of this classical comic scene. According to the "positive thinking" ideology, comedy gets turned into a "lesson meant to show us our mere humanity — to teach us that we are not perfect, that after all we are only human, that we should simply accept our weaknesses, limitations and imperfections" (Kottman 4). In Zupančič’s more radical understanding of comedy the fun part of the baron's slip on the banana peel is not so much the slip in itself, but the typical aftermath where the baron quickly gets up and walks on as if nothing had happened. The baron's unshakable belief in his own position as a baron, and his need to keep up this composure of arrogance and self-assuredness is the element that shows him to be a common human being. As Zupančič writes:

An inflexible belief in one's own baronage is precisely the point where the soul itself is as corporeal as possible. The concrete body of the baron, which repeatedly falls into the puddle of human weaknesses, is not simply the empirical body that lies flat in the mud, but much more the belief in his baronage, his "baroness." (32)

The baron's belief in his "baronness" makes him just a silly human, who believes that he is completely and naturally a baron. What this comic scene demonstrates is again a disjunction, 
since the baron's baroness is at the same time a surplus that seems added to him, and a lack, since he can never completely be a baron, since he slips and since it is a "-ness" and thereby not something natural. Repeating Zupančič's point regarding the human equation not adding up: 'If humans were 'only human(s)' (and life 'only life'), if the human equation indeed added up so neatly and with no remainder, there would be no comedy" (49). On a side note, it is curious that in Italian "una baronata" actually means a joke, and Pantalone uses this expression when he discovers the trick that il Dottore has played on him by marrying their two children behind his back: "PANTALONE. Ve digo che questa la xè una baronada" $(3,7)$. I shall get back to this marriage-baronata equivalency later.

The central conflict of marriage in the play within the play is the well-known plot of an older man, probably a widower, wanting to marry a young wife, who is actually meant for his son. The actors in Il teatro comico are rehearsing the third and last act of the play Padre rivale del figlio, so we enter the play within the play at the culmination of a marriage conflict, and then follow the untying of the knot.

Keeping Zupančič's baron-example in mind, Pantalone at the beginning of this third act makes a similar slip, not on a banana peel, but "on" the norms of marriage. Pantalone is visiting Rosaura who is home alone (so he thinks), and he is talking to her about love. In the middle of his flirting with the young girl, he discovers that Florindo has been hiding in another room and has overheard their conversation.

PANTALONE. Disé, fia mia, avéu mai fatto l'amor?

ROSAURA. No, signore, mai.

PANTALONE. No savé come se fazza a far l'amor?

ROSAURA. Non lo so, in verità.

PANTALONE. Ve l'insegnerò mi, cara, ve l'insegnerò mi.

ROSAURA. Queste non mi paiono cose per la sua età. 
PANTALONE. Amor no porta rispetto a nissun. Tanto el ferisce i zóveni quanto i vecchi; e tanto i vecchi, quanto i zóveni, bisogna compatirli co i xè inamorai.

FLORINDO. Dunque (esce) abbiate compassione anche a me se sono innamorato.

PANTALONE. Come? Qua ti xè?

FLORINDO. Si, signore, son qui per quella stessa cagione, che fa qui essere voi.

PANTALONE. [...] Onde, fóra tutti dó de sta casa. Mi per elezion, ti per obbedienza. Mi per rimediar al scandolo, che t'ho dà; ti per imparar a viver con cautela, con più giudizio, con più rispetto a to pare.

FLORINDO. Ma, signore....

PANTALONE. Animo, digo, fóra subito de sta casa.

FLORINDO. Permettetemi....

PANTALONE. Obbedissi, o te trarrò sóso de la scala con le me man. $(2,6)$

This scene can be said to follow a somewhat similar structure as the example of the baron who slips on a banana peel. Pantalone in the citation above "slips" as he shows his only too human passion for the young girl, talking to her about lovemaking. "Disé, fia mia, avéu mai fatto l'amor? [...] Ve l'insegnerò mi, cara, ve l'insegnerò mi." Right after, though, when Florindo reveals himself to stop his father's attempt to win Rosaura, Pantalone gets back up on his paternal and authoritative pedestal and acts as if nothing had happened, demanding his son to obey. "Onde, fóra tutti dó de sta casa [...] ti per imparar a viver con cautela, con più giudizio, con più rispetto a to pare [...] Obbedissi, o te trarrò sóso de la scala con le me man.” Had Pantalone not hurried to recompose himself, the scene would likely have been more tragic than comic. His inflexible belief in his own paternal authority becomes even clearer in 
his almost violent rejection of his son's explanation and plea for discussion. Pantalone's inflexible belief in his own paternal authority is what makes him (like in the case of the baron) a common silly human. Pantalone's slipping on the banana peel consists of the fact that he is just a man, an old man incompatible for a young bride; and his getting up quickly as if nothing had happened is based in his continuous belief that he is appropriate and authoritative. This scene is comic because it demonstrates a (dis)junction, since Pantalone's paternal authority and superiority is at the same time a surplus that seems added to him (he needs to act a certain way), and a lack, since he can never completely be a perfect authoritative father, because he slips and since it is a "-ness" and thereby not something natural. The comic (dis)junction has in it a potential criticism of authority and power, since it shows the unnatural and conventional constitution of hierarchical positions and thereby also opens a room for questioning and revolt. I shall next examine Goldoni's comic mechanisms from the perspective of their subversive potential.

\section{Goldoni's subversive comedy}

Goldoni is usually perceived as advocating for moderation and the "golden mean." $\mathrm{He}$ wanted his comedies to be didactic and useful for the audience, without radical or scandalous scenes (as mentioned before Goldoni was against scenes with vulgar language, beatings, women in the streets). Also, at the end of Goldoni's plays everything is sorted out, the comedy comes to an end, paternal order is restored and socially acceptable marriages are held. As the Goldoni scholar Joseph Judicini has pointed out, Goldoni was by temperament a peaceful soul, and he was obliged to please his payers and pass through the Inquisition's censorship on plays (215-216). Judicini's conception of Goldoni's comedies as somewhat conservative and inoffensive is in line with the usual perception. Although these aspects of Goldoni's comedies and life are true, it does not make his comedies less subversive. 
The happy ending of Goldoni's plays might not be as conservative as they are often interpreted as being. A modern audience might see Goldoni's wish for moderation and usefulness as conservative, but the happy ending is not in itself conservative from a comic point of view. As Zupančič states:

In comedy, they say, things always add up to everybody's satisfaction. This view about everything adding up is quite persistent, although it is difficult to reconcile with the host of misencounters, misunderstandings, miscalculations, mistakes, misstatements, misrepresentations, misplacements, mismovements, misjudgments, misinterpretations, misdoings, misconducts and misfirings on which comedy thrives. One usually pushes all these aside simply by saying that they are only temporary, and always lead to a final harmony and general satisfaction. Against this view, several assertions must be made. (130) According to Zupančič, the comic happy ending is not a sudden reversal of a previous misfortune or unhappiness, but is instead perfectly consistent with the joyful satisfaction that has lived all through the comedy, and is produced precisely by the misunderstandings, mistakes, misfiring etc. As Zupančič futher argues: "Indeed - if anything, the comic happy ending, rather, comes with a certain amount of disappointment, since it implies the end of comedy and of its specific pleasure. In other words, comedy and comic satisfaction thrives on things that do not exactly add up" (130). Comedy thrives on these discrepancies or disconnections because they are a source of pleasure, laughter and fun, rather than pain and sorrow.

In Il teatro comico, we see how a misunderstanding in the play within the play, Padre rivale del figlio, is what brings about the central marriage between the two young lovers. The formative connection between the misunderstandings and the happy ending of the marriage is articulated very clearly by Il Dottore, who literally states that the mistake has produced the 
marriage. In this scene Pantalone is furious, because il Dottore has married their two children without his consent, and Il Dottore misunderstands Pantalone's words.

DOTTORE. Ditemi, di grazia, non avete voi desiderato che mia figlia fosse sposa del signor Florindo?

PANTALONE. No xé vero gnente!

DOTTORE. Avete pur detto a lei di volerla maritare in casa vostra?

PANTALONE. Sior si, ma no co mio fio.

DOTTORE. Dunque con chi?

PANTALONE. Con mi, con mi.

DOTTORE. Non credeva mai che in questa età vi soprendesse una simile malinconia. Compatitemi, ho equivocato; ma questo equivoco ha prodotto il matrimonio di vostri figlio con Rosaura mia figlia." $(3,7)$

Il Dottore misunderstands Pantalone's words about marrying Rosaura into his house. Pantalone intended her as his own bride, and il Dottore of course thought Rosaura to be the bride of Pantalone's son Florindo. Il Dottore literally says that the misunderstanding has produced the marriage (the happy ending): "Compatitemi, ho equivocato; ma questo equivoco ha prodotto il matrimonio di vostro figlio con Rosaura mia figlia." The happy ending is consistent with the comic pleasure and satisfaction produced by disjunctures and misunderstandings because they are a source of pleasure, laughter and fun. The happy ending implies some disappointment as well, since it implies the end of comedy and of its specific pleasure.

In her article "On the Deceptions of the Deceived: Lelia and The Pleasures of Play" Laura Giannetti also points to the fact that comedy opens up a delightful space of giochi that ends when the comedy ends. She writes: "usually when gioco comes into play, time and space are emptied of their quotidian power constraints - fathers, husbands, patrons, authority 
all are momentarily absent. That absence, in fact, is necessary to create the space and time for gioco" (85). Giannetti's description of a space and time for gioco can be understood as the space of misunderstandings, misplacements, misinterpretations and misfirings that comedy produces and thrives on. Giannetti, as Zupančič, identifies a playfulness to comedy that is not just a funny game, but which implies a deep and rich structure: "considering Renaissance comedy as merely a game is not enough to explain the central role of gioco in the genre. The gioco of Renaissance comedy is far richer. [...] I would argue the other meaning of gioco in English - play. The playfulness constitutes the deep structure of comedy" (Giannetti 56).

Playfulness and subversion play a fundamental role in Goldoni's comedy. The gioco implements the same shaking up of the system that is described in the comic disjunctions. The gioco or comic sequence of disjunctions disturbs hegemonic meanings, because it shows that something does not add up. The important part of comedy is not its happy endings, but instead the playful and potentially disturbing and subversive gioco or disjunctions that it exposes to us and about which we can laugh while the game is on.

\section{Conclusion}

There is something mysterious about comedy, and it might have to do with the fact that the second book of Aristotle's Poetics concerning comedy and laughter, is missing. Goldoni in Il teatro comico invites us backstage (behind the curtain). The opening of the play points our attention to the fact that Il teatro comico is a meta play about playwriting and acting, and it arouses our curiosity, as we are let behind the curtain to see both the plot of the new play, but even more importantly, the workings of comedy. In her revival of the sparkling, cutting edge of true comedy, Zupančič advocates for a critical and subversive quality to comic mechanisms or workings on the level of the play as text. Comedy through its (dis)junctions demonstrates how two heterogeneous orders when crossed simultaneously 
Kristensen 30

show a connection and a lack or gap in meaning, creating something extra, a surplus. This surplus then generates ground for further comedy as it makes new mismatches, misunderstanding and meanings that do not add up. In Il teatro comico we see several examples of such comic (dis)junctions.

In Goldon's witty critique of Lelio's old style dialog a (dis)junction occurs between the two heterogeneous orders, one being the presented dialog uomo prega, donna scaccia and the other Lelio and his own situation at the theatre. Starting out as a dialog between two lovers, it becomes a dialog between Lelio and his listeners. The listeners' engagement with the repetitions, rhymes, metaphors and other rhetorical figures such as antithesis and chiasmus of the dialog cited by Lelio causes the two orders (Lelio's dialog and the actors' responses) to swing the meaning back and forth in a movement of mismatches where the meaning continues to change retrospectively. In this way, Goldoni's (play)writing becomes a "telling by showing" as he through a clever observation of the old style dialog, at the same time shows how the new style's thoughtful and scripted wordplay and interactions between the actors can produce great comedy. On the level of the play as text the comic disjunctions create a comic sequence and show a potentially radical and subversive aspect inherent in Goldoni's comedy.

Another comic disjunction is inscribed in Lelio's comic character, and shows his Ego and his Id as being simultaneously split and tightly connected. Lelio as the comical protagonist of Il teatro comico is torn between his idea of himself as a respectable poet (the Ego) and his Id's unconditional desire and need to get a job and thereby food, in spite of any obstacle, insult or dishonor it might cause for his Ego.

Finally, Pantalone in the play within the play, Padre rivale del figlio, makes a comic slip, as he flirts with Rosaura and is discovered. The scene demonstrates a (dis)junction, since Pantalone's paternal authority and superiority is both a surplus that seems added to him (he 
needs to act a certain way), and a lack, since he can never completely be a perfect authoritative father. His paternal authority is a "-ness" and thereby not something natural. The comic (dis)junction has in it a critical potential of authority and power, since it shows the un-immediate, unnatural and conventional constitution of hierarchical positions and thereby also opens up a space for questioning and revolt.

Goldoni's rules about how to write good comedies are playfully inserted in the dialogs of Il teatro comico. It is a play about how to make good plays, and it can be understood as a kind of manifesto using a "telling by showing" approach to explain Goldoni's ideas about playwriting. The play has a meta form where actors play actors who are rehearsing a play, and where the conventions of playwriting are discussed in their dialogs. By focusing our attention on an additional way these rules and theories are discussed and presented, and following Zupančič's idea about the mechanisms and movements of comedy, we see that Goldoni was a lot more subversive, at least in his comic mechanisms, than he is often understood to be. Contrary to the usual conception of Goldoni's comedies we find a literary pleasure when we look closer at his rhetorical figures, stylistics and comic effects. 


\section{Works Cited}

Crotti, Ilaria. Libro, Mondo, Teatro. Venezia: Marsilio, 2000.

Fido, Franco. Nuova guida a Goldoni. Teatro e società nel Settecento. Torino: Einaudi, 2000.

---. “Goldoni oggi (1707-2007).“ Italica 83.3 (2006): 707-716.

Forbes, Jill and Michael Kelly, ed. French Cultural Studies - An Introduction. Oxford: Oxford University Press, 1995.

Giannetti, Laura. "On the Deceptions of the Deceived: Lelia and The Pleasures of Play." MLN 116.1 (2001): 54-73.

Goldoni, Carlo Emilio. Il teatro comico. Milano: Signorelli, 1969 [1750].

Judicini, Joseph. "The Problem of the Arranged Marriage and the Education of Girls in Goldoni’s 'La figlia obbediente' and Moratín's 'El sì del la ninas'.” Rivista di letterature moderne e comparate 24 (1971): 208-223.

Kottman, Paul A. "Slipping on Banana Peels, Tumbling into Wells: Philosophy and Comedy." Diacritics 38.4 (2008): 3-14.

Lacan, Jacques. Écrits. Paris: Éditions du Seuil, 1966.

Zupančič, Alenka. The Odd One In. On Comedy. Cambridge, Oxford: MIT Press, 2008. 